\title{
Güncel Resimde Etnik Kimlik: Chris Ofili Örneği
}

\section{Ethnic Identity in Contemporary Painting: The Case of Chris Ofili}

\section{Ünal Bastaban}

Arş. Gör., Kafkas Üniversitesi, Dede Korkut Eğitim Fakültesi, Resim-İş Eğitimi Bölümü

email: bastabanunal@gmail.com DORCID ID: https://orcid.org/0000-0003-1172-8374

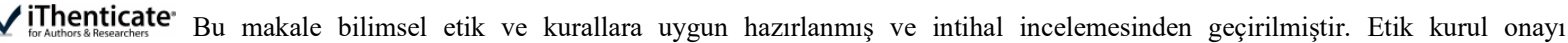 \\ gerektirmemektedir.
}

Atıf (APA 7)/To cite this article

Bastaban, Ü. (2021). Güncel resimde etnik kimlik: Chris Ofili örneği. Atatürk Üniversitesi Güzel Sanatlar Enstitüsü Dergisi, 27(47), 453462. doi: https://doi.org/10.35247/ataunigsed.909781

Makale Gönderim Tarihi/Received: 05/04/2021

Makale Kabul Tarihi/Accepted: 12/07/2021

Makale Yayın Tarihi/Published: 28/10/2021

Review Article / Derleme Makale

$\ddot{\mathbf{O} z}$

Yüzyılların tarihi bilgi ve belgeleri öteki olana karşı duruşlarla doludur. Bu çatıșma çeșitli bilim dallarını etkilediği gibi sanatsal faaliyetlerinde yansitma aracı olmuştur. Görsel hafizanın aktarıcısı olan sanatçılar çağların bu çatıșmalarına tanıklık etmişlerdir. Bu çalışmada da etnik kimlik kavramından yola çıkılarak, insanlığın karşılaştığı çeşitli çevresel, sosyo-kültürel ve ekonomik yansımaların bir dışavurumu olan güncel sanatta etnik kimlik kavramını Nijerya asıllı bir İngiliz güncel sanatçısı olan Chris Ofili'nin Neo-Expresyonist yaklaşımılyla bağlantılı olarak ortaya koymak amaçlanmıştır. Araştırma sanatsal ve güncel temelleri olan bir konuyu kapsaması nedeniyle sınırlar ve kaynaklar cessitli ve belirsiz olabilmektedir. $\mathrm{Bu}$ nedenle araştırmada nitel araştırma desenlerinden durum çalışması kullanılmıștır. Araştırmada veri toplamak amacıyla nitel araştırma yöntemi veri toplama tekniklerinden doküman incelemesi kullanılmıştır. Araştırmada veri elde etmeye yönelik, kütüphanelere, ulusal tez merkezine ve internet kaynaklarına ulaşılarak; kitap, tez, makale, dergi ve bilimsel temelli internet yazıları gibi kaynaklar taranmıștır. Araștırmanın anahtar kelimeleri doğrultusunda tarihsel sinırlama yapmadan tarama yapılmıştır. Araştırmada siyasi ve dinsel amaçlar doğrultusunda gerçekleșen ötekileștirme olaylarının kültürel bellek ile sanata gelenek bağlamında aktarılması irdelenmiştir. Güncel İngiliz sanatçısı olan Chris Ofili'nin yaptığı çalıșmalarla etnik kimlik ve kültürel bellek bağlantıları yorumlanmış ve ortaya konulmuştur. Çalışmada ötekileştirme yaklaşımlarının sanata yansımaları arastırılmıs olup, Chris Ofili'nin yapıtlarındaki anlamsal vurgulamalar ile çalışma desteklenmiştir. Chris Ofili'nin çalıșmalarıyla ve ortaya koyduklarıyla siyahî kimliği, Afrika köklerini, batı medeniyetinin atalarına ve diğer toplumlara bakış açılarını ve tutumlarını yine batının birtakım kutsallarını alaycı bir biçimde ele alarak ince mesajlarla ortaya koyduğu sonucuna ulaşılmıştır. Chris Ofili, yaptığı çalışmalarla yeni nesillere kendi kültürünü korumak, kimliğine sahip çıkmak ve sorgulamadan kabullenmemek gibi mesajlar bırakmıştır.

Anahtar kelimeler: Güncel Sanat, Neo-Exspresyonizm, Etnik Kimlik, Chris Ofili.

\begin{abstract}
The historical information and documents of the centuries are full of stances against the other. This conflict has affected various branches of science and has been a means of reflection in their artistic activities. Artists who are the transmitters of visual memory have witnessed these conflicts of the ages. This study, based on the concept of ethnic identity, aims to reveal the concept of ethnic identity in contemporary art, which is an expression of various environmental, socio-cultural, and economic reflections faced by humanity, in connection with the Neo-Expressionist approach of Chris Ofili, a British contemporary artist of Nigerian origin. The boundaries and resources can be varied and uncertain because the research covers a subject with artistic and contemporary foundations. For this reason, a case study, one of the qualitative research designs, was used in the research. Document analysis, one of the qualitative research method data collection techniques, was used to collect data in the study. By reaching libraries, the National thesis center and internet resources for obtaining data in research; Resources such as books, thesis, articles, journals, and scientific-based internet articles were scanned. In line with the keywords of the research, a search was made without historical limitations. In the research, the transfer of marginalizing events that take place for political and religious purposes to art and cultural memory in the context of tradition was examined. Ethnic identity and cultural memory connections have been interpreted and revealed through the works of Chris Ofili, a contemporary British artist. In the study, the reflections of other approaches on art were investigated and the study was supported with the semantic emphasis in Chris Ofili's works. It has been concluded that Chris Ofili, with his works and manifestations, revealed his black identity, African roots, the views and attitudes of the western civilization towards his ancestors and other societies with subtle messages by taking some of the saints of the west in a mocking way. It can be said that Chris Ofili left messages to new generations such as protecting her own culture, embracing her identity, and not accepting it without question.
\end{abstract}

Keywords: Contemporary Art, Neo-Expresyonizm, Ethnic Identity, Chris Ofili

\section{Giriş}

Sanat, kültürden kültüre değişen ve birçok açılımı olan bir kavramdır. İnsanlığın varlığı ile birlikte sanat kavramının da ortaya çıktığı düşünülmektedir. Sanat, ilk insanlarca yapılan çeşitli şekil ve biçimlerle karşımıza çıkmaktadır. Bilinçli ya da bilinçsiz bir şekilde birtakım araçlarla bazı eşyaların üzerine kazınan görseller ilk sanatsal faaliyetler olarak adlandırılabilir. Bu biçimsel düzen zamanla toplumsal bir gösterge olarak kültür ve sanat faaliyetleri ile yoğrula gelmiştir. Zamanla değişen toplumsal adetler, törenler değişik etmenlerle evrimleşmiş ve buna paralel olarak sanat da değişim göstermiştir. Sanatını ortaya koyan sanatçı da bu bağlamda içinde bulunduğu çağı takip eden çalışmalar ortaya koymaktadır. 
Çağının çocuğu olan sanatçıların kendi özünden ve kültüründen bağımsız eserler vermesi onu ne kadar başarılı kılar? Sanatçı kendi bilinçaltında biriktirdiği kültürel geçmişini yadsıyarak ve kültürüne yabancılaşarak ne derece özgür olabilir? Siyahî asıllı Chris Ofili'de kendi köklerini ve etnik kimliğini çalışmalarında kullandığı malzeme ve tarzıyla özgür bir biçimde yansıtan genç İngiliz sanatçılarındandır. Bu çalışmada da etnik kimliğin, kültürel geçmişin ve ayrımcı-ırkçı tutumların güncel sanata yansımaları, güncel ve Neo-Expresyonist sanatçı Chris Ofili'nin çalışmalarındaki göndermeler ile bağlantılı olarak ortaya koyulmaya çalışılmıştır. Güncel sanat, etnik kimlik, Neo-Expresyonizm ve Chris Ofili anahtar kelimeleri bağlamında kavramlar açımlanarak geçmiş ve günümüz ile bağlantılar kurulmuştur. Bu bağlantılarda özellikle ötekileştirilen siyahilerin sanatsal çalışmalarda zamana ve düşünce değişimlerine göre yansitılma biçimleri irdelenmiştir. Chris Ofili siyahi kimliği ile güncel sanatta özgün bir biçem elde etmesi ve kültürel belleği canlı tutan çalışmaları ile tepkiler çekmesi nedeniyle çalışmamıza konu olmuştur. Kendi Afrikalı kimliğini batının gözü önünde farklı şekillerde göndermeler yaparak çalışmalar ile ortaya koymaktadır. Bu durum da onu sanatıyla özgür kılmaktadır denilebilir.

$\mathrm{Bu}$ çalışmada etnik kimlik kavramından yola çıkılarak, insanlığın karşılaştığı çeşitli çevresel, sosyo-kültürel ve ekonomik yansımaların bir dışavurumu olan güncel sanatta etnik kimlik kavramını Nijerya asıllı bir İngiliz güncel sanatçı olan Chris Ofili'nin Neo-Expresyonist yaklaşımıyla bağlantılı olarak ortaya koymak amaçlanmıştır.

\section{Yöntem}

Araştırma sanatsal ve güncel temelleri olan bir konuyu kapsaması nedeniyle sınırlar ve kaynaklar çeşitli ve belirsiz olabilmektedir. Bu nedenle araştırmada nitel araştırma desenlerinden durum çalışması (case study) kullanılmıştır. "Durum çalışması, güncel bir olguyu veya durumu kendi doğal gerçekliği içinde işe koyan, olgu ve içinde bulunulan içerik arasındaki sınırların tam olarak belirgin olmadığı ve çok çeşitli veri kaynağının olduğu durumlarda kullanılan bir araştırma yöntemi olarak tanımlanmaktadı"” (Yıldırım \& Şimşek, 2009).

Araştırmada veri toplamak amacıyla nitel araştırma yöntemi veri toplama tekniklerinden doküman incelemesi kullanılmıştır (Creswell, 2020, s. 108). Araştırmada veri elde etmeye yönelik, kütüphanelere, ulusal tez merkezine ve internet kaynaklarına ulaşılarak; kitap, tez, makale, dergi ve bilimsel temelli internet yazıları gibi kaynaklar taranmıştır. Araştırmanın anahtar kelimeleri (etnik kimlik, güncel sanat, Chris Ofili, NeoExpresyonizm) doğrultusunda tarihsel sınırlama yapmadan tarama yapılmıştır. Tarama neticesinde araştırma konusu ile bağlantılı yaklaşık 83 kaynağa ulaşılmış olup, doğrudan çalışmayla ilgili olan; 3 kitap, 11 tez, çeşitli dergilerde yayımlanan 9 makale ve 1 internet kaynağına yer verilmiştir.

Araştırmada siyasi ve dinsel amaçlar doğrultusunda gerçekleşen ötekileştirme olaylarının kültürel bellek ile sanata gelenek bağlamında aktarılması irdelenmiştir. Güncel İngiliz sanatçısı olan Chris Ofili'nin yaptığı çalışmalarla etnik kimlik ve kültürel bellek bağlantıları yorumlanmış ve ortaya konulmuştur. Çalışmada ötekileştirme yaklaşımlarının sanata yansımaları araştırılmış olup, Chris Ofili’nin yapıtlarındaki anlamsal vurgulamalar ile çalışma desteklenmiştir.

Araştırmada etik ilkelere uygun bir şekilde veri toplanmış ve elde edilen veriler objektif bir şekilde rapor edilmiştir. Araştırmaya kaynak sağlayan veriler ve fikirler kaynak gösterilerek belirtilmiştir.

\section{Bulgular ve Yorum}

\subsection{Güncel Sanatta Etnik Kimlik Yansımaları, Irkçı Yaklaşımlar ve Chris Ofili Örneği}

Yaşam şekillerinin değişimi sanatı ve sanatçıyı her dönemde etkilemiştir. Bu değişim kimi zaman çok aniden kimi zamanda uzun soluklu ve sancılı olabilmektedir. Bireylerin kendilerini ifade etmelerinde ki her iyileşme sanatında kendini daha özgür yansıtmasında etkin rol oynamıştır. Bu değişim sürecinin bir parçası olan sanatta modernleşme, farklı bakış ve düşünme hareketleriyle aynı paralelde ilerlemiştir. Sanat adına farklı düşünme ve düşünceyi yansıtabilme 20. yüzyılın ikinci yarısından itibaren tam anlamıyla vücut bulmuştur denilebilir.

Önceki dönemlere göre olumlu anlamda değişim olarak isimlendirilen modernleşme; hem ekonomik ve yaşam biçimlerinin kapsadığı belirli bir zamanı hem de o dönemde hâkim olan anlayışı ifade etmektedir. Sanat da bu döneme etki eden düşünceyi ve idealleri belirlemede etkili bir alandır (Erdoğan, 2015, s. 78). 1960'ların çeşitli alanlardaki siyasi ve toplumsal dinamizmi sanatsal bağlamda da radikal yenilik ve sorgulamaları meydana getirmiştir. Gelenekselleşmiş kalıp fikirlere bir başkaldırı süreci ortaya çıkmıştır. Çünkü sadece belirli alanları kapsayan sanatsal faaliyetler artık ötekileştirilmişlerinde içerisinde bulunduğu bir yapıyı içerisinde bulunduran bir hal almıştır. Toplumsal yapıdaki bu siyasi, etnik, ekonomik ve kültürel değişimler ile fertlerde meydana gelen özgür tavırlar sanatın da baskılanmış çalışma alanını etkilemiştir. Bu değişimler sanatta çok farklı akımlar doğurmuştur. $\mathrm{Bu}$ dönemde meydana gelen gelişmeler 1960'larda akımların, fikirlerin ve düşüncelerin yansımalarıyla belirginlik kazanmıştır. Modern sanat adına 1960'lı yıllar bu yansımaların taşıyıcısı olduğundan oldukça önemli sayılmaktadır. 
Güncel sanat kavramı hakkında birçok tanımlama vardır. Bu tanımlamalardaki en belirgin benzerlik; güncel sanatın belirli bir akımı kapsamayıp, her zaman öncü olma çabasıdır. Andırın (2019), güncel sanatı şöyle tanımlar: "çağdaş kelimesinin bize belirttiği gibi çağımıza ait olan, günümüz sanatını işaret etse de içinde aykırılıklar barındıran bir başkaldırıdır. Yaşadığımız çağın sanatını temsil etmesi düşünülürken aslında çağının önünde yol alan, içinde bulunduğumuz çağa başkaldıran sanat üretimini ifade etmektedir” (s. 21).

Fakat güncel sanatı üretim şekillerine ve akımlara göre açıklamak zordur. Çünkü toplumsal duyarlılığın ve çevresel bilincin uçlarına dokunan konularla ilgilenmiştir. 'Güncel' yirminci yüzyılın ikinci yarısından günümüze kadar gelen ve herhangi akım ve üslup bakımdan birbirini taklit eden yönü olmayan sanat akımlarının genel adı olarak adlandırılmıştır. Bu nedenle çağının öncüsü olan günceli anlamak aynı zamanda bizlere söylemek istemediği şeyleri de tahmin etmek, bıraktığı boşlukları doldurmaktır. Güncel sanatta, çok çeşitli çalışma tarzları sanat bağlamında akım, üslup gözetmeksizin karşımıza çıkmaktadır. "Üstelik de bunu yaparken, günümüz dönemde diğer dönemlerde olduğu gibi yıkarak değil, üst üste eklenerek, kendine dâhil ederek yeniden yorumlayarak gerçekleştirmekte" (Atl1, 2018, s. 20).

Güncel sanat etnik dışavurum, çevre, savaş, zorbalık, maddiyat gibi kapsayıcı konuları ele aldığı için her birey kendinden bir şeyler bulabilir. Güncel sanatçılar da kendi kültürel alt yapılarında getirdikleri (belki ötekileştirilmiş) öz kimliklerini güncel olayların etkisiyle çalışmalarına yansıtmaktadırlar. Çünkü "Sanatçının doğumuyla başlayan süreç; yaşadığı dönem ve toplumsal koşulların yönlendiriciliği ile sıkı bir bağ içerisindedir" (Ağçiçek, 1991, s. 2). Fakat bunu yaparken öz kültüründe kutsal olan ve başkaları için garip duran maddeleri çalışmalarında anlamsal ve vurgusal bir biçimde kullanabilmektedir (Chris Ofili'nin fil dışkısını çalışmalarının kutsalı olarak tuvallerine yerleştirmesi gibi). Bu bağlamda, sanatçının ürettikleri kendisinin de içerisinde bulunduğu toplumun geçmişinden izler barındırır. Hayal ürünü olan üretimler, sanatçıların kendi kültürel kimliklerine ait argümanları birlikte kullanmalarına izin vermekte olup sanatçıların hafızalarına attıkları kalıcı belleklerinden getirdikleri imgeleri kullanarak arada bulunan sınırları aşan yaklaşımları ortaya koymaktadır. (Erkayhan ve Ödekan, 2008, s. 26).

Tabi çoğu dönemde olduğu gibi çağdaş denilen dönemde de sanatsal faaliyetlerin bir kısmı parasal düzenin parçası ve yönlendirmesi içerisindeki bir yapıya girmiştir. Sanat çalışmaları ekonomik kaygılar içerisinde yok olma durumuna gelmiştir. Güncel sanatın oluşan piyasası kolleksiyonerlerin ve kapital düşünce sahiplerinin elinde parasal bir araç haline gelmiştir denilebilir. "Piyasanın çağdaş sanat ortamındaki etkin rolü, "kaç?" ile başlayan soruları beraberinde getirmiştir" (Selçuk ve Selçuk, 2017, s. 2235).

Neo-Expresyonizm kavramı da bu kapitalist dünya düzenine karşı duruşun ifadesi olarak ortaya çıkan bir sanat akımıdır. "Yeni Dışavurumcu akımın temelinde, 1968 Öğrenci hareketleri, Almanya'nın bölünmesi ve Berlin duvarı, Post-modern anlayışlar, 1980'lerin yaşamı, çevre kirliliği, terör, kent yaşamı, II. Dünya savaşının psikolojik izleri, iç savaşlar, tüketim çılgınlığı, medya dibi birçok durum vardır” (Tarzan, 2010, s. 2).

Bu akım, 1980'lerde 'figürsel çalışmalara farklı bir biçim bakış açısı getiren' olarak nitelendirilmiştir. Kişilerin ve kurumsal yerlerin ketum ve kuralcı yapılarının kırıldığı 1980’lerde siyasal, ekonomik ve kültürel yönden önemli değişiklikler yaşanmıştır. Böyle bir dönemde Yeni dışavurumcuların resimsel çalışmalara yönelmesinin altında yatan sebep de: sekülerleşen-kapitalleşen toplum kitlelerinin yaşam biçimlerine, çabucak yapılan ve hemen tüketilen ürünlerin içerisine sanat nesnesinin de dâhil edilmesidir. Böylelikle sanat, güncel fikirlerle şekillenen, farklılaşan, daha popülist hale gelmiş, eski anlam ve işlevini yitirmiştir. Sanatçıların çalışmalarında ortak bir karşı duruş ve bunalımların yansıtılması vardır.

Yeni dişavurumcular benliğini kaybetmiş, adeta anonimleşmiş olan bireylerden tekbir birey oluşturmak için mesajlar veren ve geçmişi sorgulama-yeniden kendin olma duygusunu oluşturma uğraşı peşinden koşanlardan oluşmaktadır (Akkaya, 2007, s. 53). İmge ve bilinçaltının cazibesinden ziyade yeni dışavurumcular: çok önemsenmeyen belki de unutulan geçmişe yönelmişlerdir.

Neo Ekspresyonizm, Kavramsal ve Minimalist sanatın bir kenara ittiği tuval resmi ile geleneksel kültürel değerleri yeniden gündeme getirmiştir. Ayrıca Neo Ekspresyonist sanatçılar, tarihi gerçekliği yansıtan yeni anlatım yolları bulmuşlardır. Bu anlatım yolları toplum dışına itilmiş değerlerin oluşturduğu yeni bir gerçeklik ile düşsel imgelerin yeniden ortaya çıkması olarak belirginleşmiştir (Ataseven, 2011, s. 102).

Sanatsal çalışmalar her zaman özgür ve istediğini yansıtan bir alan olmamıştır. Sanat, kimi zamanda özgür yaşam şartlarının kısıtlandığı, ortaya ötekileştirilmiş toplulukların çıktığı, insanların etnik kimliği ya da görüntüleriyle yargılandığı dönemlerin yansıtılma aracı olmuştur. Tarihin çoğu döneminde toplumdaki bireyler arsında 'üstün olan benim' düşüncesini taşıyan kişilikler çıkmıştır. Bu nedenle de kimlik kavramı bir tartışma alanı olarak sanatta sıkça kullanılmış olup, kültür üzerine yapılan çalışmalarda da en çok rastlanan anahtar kelimeler arasında yer almaktadır.

Tarihin nerdeyse her döneminde siyahî topluluklara yönelik ötekileştirme ve dışlama var olmuştur. Bazı toplumlarda derisinin rengi farklı olan bu insanlar köleleştirilerek en ağır işlerde çalıştırılmışlardır (Gazi ve Çakı, 
2018, s. 49). Batı dünyasının etnik kimliği ve derisinin rengi farklı olan topluluklar ile ilgili kötü dönemleri olmuştur.

Çolak (2018), Batı dünyasını şu şekilde ifade eder: "Irkçı Avrupalılara göre asil olunmaz, asil doğulur. Başka bir deyişle, Avrupalı olunmaz, Avrupalı doğulur. Onlara göre insanlığın en üstün, beyaz ve arî ırkı Avrupalılardır. Daha doğrusu Anglo-Saksonlar ve Cermenlerdir" (s. 1). Bilen (2019) da Batı'nın yani batıdan kasıt; Amerika, Avrupa, Büyük Britanya toplumlarının bu düşüncesinin temellerinin dayanak noktasını şöyle ifade eder: "Alatlı, Batılı dünya görüşünün sebep olduğu problemlerin temelinde, insanın konumlandırılması meselesi olduğunu düşünmektedir. Batı'daki her gelişme aslında insana dair temel bazı varsayımlara dayanır. Bu varsayımların başında da insanın dünyaya istek ve arzularını tatmin etmek için gelmiş olduğu düşüncesi gelmektedir" (s. 19). Bu tatminleri peşinde koşan medeni Batı'nın öteki olana el uzatış biçimi Görsel 1'de görülmektedir.

\section{Görsel 1}

Batı'nın İnsan-Hayvanat Bahçelerinden Acı Bir Kare, 1958, Belçika

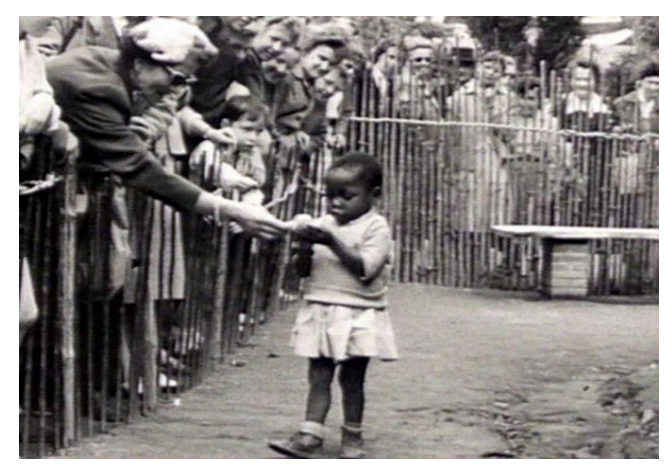

(Avrupa Birliği Gazetesi, 2016)

Ortaçağ yaşamında yerini alan kölelik, Yeniçağ 'da Amerikan sömürge mantığıyla kendini yenilemiş ve Avrupa koloni sistemi ile de toplu zenci köle ticareti iyice cazibeli hal almıştır (Özer, 2007, s. 67). Avrupa toplumlarının 'buldum' sevdasıyla saldırdıkları Amerika kıtasının bakir toprakları yine aynı toplumların gemilerle Afrika ve benzeri coğrafyalardan getirilen ve en ağır zulümlere maruz kalan ve işlerde çalıştırılan köleleştirilmiş insanlarla doldurulmuştu.

Çoğu haklardan mahrum bırakılan, köleleştirilen bu insanlar, hayvan muamelesi görmüşlerdi. Rengi ve görünüşleriyle eğlenilen, maymun ve gorillerle aynı kafeslere konulan dünyanın çeşitli yerlerinden getirtilen bu insanlar, milyonlarla ziyaretçinin ziyaret ettiği 'görülmeye değer' bir duruma gelmişti. Fotoğraf sanatının bu anları tarihi kayıt haline getirdiği duruma dayanamayıp intihar eden köleler olmuştur. Yöresel dillerinde dost anlamına gelen Ota Benga isimli baba da bunlardan biridir. Görsel 2 New York'ta bulunan Bronx Hayvanat Bahçesi'nde İnsanın Eski Ataları adı altında sergilenmiştir.

\section{Görsel 2}

Ota Benga'nın, Bronx Hayvanat Bahçesi'nde Bir Maymunla Çekilmiş Resmi

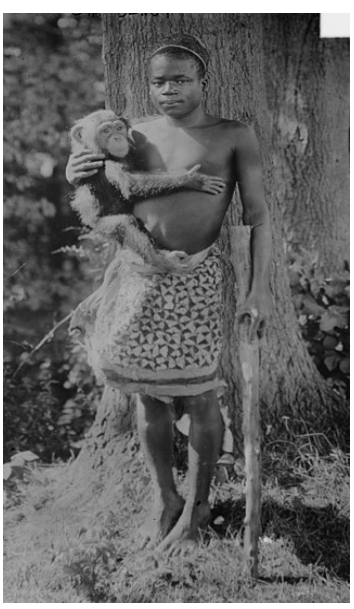

(Library of Congress, 1906)

19 yaşında ve iki çocuk babasıyken köleleştirilen Ota Benga, maymunla beraber aynı kafeste ve çeşitli mekânlarda bulundurulmaya zorlanan siyahî bir Afrika pigmesi köle olarak insan-hayvanat bahçelerinin sembol 
ismi olmuştur. 1903 senesinde, Ota Benga, başarılı bir fil avından dönerken yakalanarak köleleştirilmiştir. Ziyareti için ayrı, dişlerinin farklı görünüşünden dolayı gülmesi için ayrı ücret veren izleyici kitlesindeki zamanla aşağıya doğru iniş Ota Benga'nın da serbest bırakılmasına sebep olmuştur. Fakat Ota Benga o kadar aşağılanmıştır ki dayanamayıp intihar etmiştir.

Avrupa'da ve Amerika'da yaşanan bu olayların düşünsel alt yapılarının köklerini yansıtan sanatsal çalışmalar eskiden olduğu gibi sonraları da yapılmıştır. Üstün ırk olan "beyaz insan" tablolarda da yansıtılma biçimiyle bu düşünceyi tamamlamıştır. Avrupalı kimi ressam bu aşağılayıcı insan tutumlarının yansımalarını subliminal mesajlar kullanarak çalışmalarına yansıtmışlardır (Örnek: Görsel 3 ve Görsel 4).

\section{Görsel 3}

Kraliçe Viktorya Windors Şatosunun Kabul Salonunda İncil Sunarken

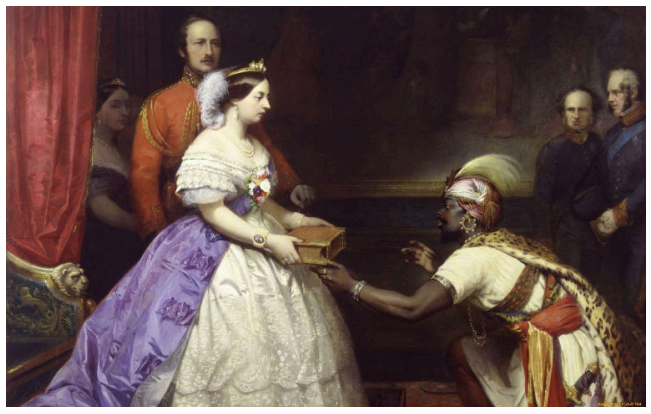

(Barker, 1863)

Leppert "habis öteki" bakış açısını tanımlarken, On dokuzuncu yüzyılın en tanınmış fizyonomi bilginlerinden biri olan Samuel R. Wells’ in görüşlerinden edindiği şu satırlara değinir:

Tipik zenci için şunları söyleyebiliriz: Huy olarak yavaş ve uyuşuk, fakat çok dayanıklı ve dirençlidir [ki bu yenice lağvedilmiş köleliğin başarısının özüydü]. Beyinsel gelişim açısından ise şehvetli, tutkulu, sevecen, iyiliksever, uysal, taklitçi, adakçı, hurafeci, heyecanlı, patavatsız, kibirli, savurgan, kurnaz, kibar ve ilkesizdir. [Bu özellikler o dönemlerde daha çok ya kadınlarla ya da evcil hayvanlarla özdeşleştirilen özelliklerdi.] İdealden ziyade gerçekle yaşar ve kafasını geçmişe de geleceğe de takmadan şimdiki zamanın keyfini çıkarır. Zihinsel gelişim açısından bir çocuktur, bir çocuğun erdem ve kusurlarına sahiptir ve tıpkı bir çocuk gibi denetlenebilir, disipline edilebilir, eğitilebilir ve geliştirilebilir (Wells'den aktarıldığı gibi Leppert, 1996, s. 280).

Avrupa'nın düşünsel temellerini oluşturan ünlü bilginlerinin insanlar hakkındaki düşüncelerini yansıtan bu paragraf, Batı dünyasının bugünkü durumunu açıklar niteliktedir. Zira bugün sınırlarda bekletilen milyonlarla ifade edilen mültecinin ya da kendini üstün ırk gören toplumlarda siyahî ve doğulu insanların yaşadıklarının geçmişte yaşanılanlardan çok da farklı olmadığı söylenebilir. "Tek dişi kalmış medeniyet” sözü bu durumu doğrular niteliktedir.

Sanatsal olarak bu düşüncelerin çalışmalara yansımasına devam edecek olursak, insanın en doğal hakkı olan gülmek dahi ırkçı bir tutumla tablolarda yer bulmuştur.

\section{Görsel 4}

Olmamış mı? (Ain't That Ripe?)

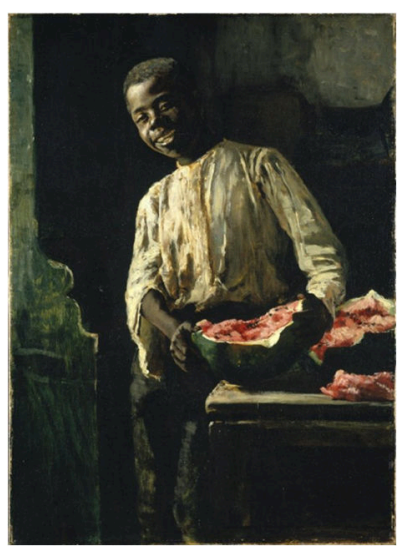

(Hovenden, 1885) 
"Biz kim o kim ve bizden değil ama kullanılabilir bir nesne" gibi görülen beyaz ırk dişında olan her toplum, zamanın çoğu Batı sanatçısının resimlerinde kendini göstermiştir. Avrupa'nın bir dönem düşüncelerine hâkim olan gülmenin aşağılık ve sıradanlık göstergesi olduğu zamanlarda siyahî insanların tablolarda giyim şekliyle, duruşuyla basitleştirilmiş ve gülerek resmedilmesi bu aşağılayıcı tutumların bir yansıması olarak görülebilir.

Ekonomik çıkarlar ve kültürel yapılanmaların oluştuğu küresel piyasa hem çağdaş dünyada yer edinmeye çalışırken hem de varlığını kolonileştirme üzerinden yürütmüştür. Bu çelişkili durum sanat için cazibesine karşı konulamayan zıtlıklar oluşturmuştur. Nitekim güncel sanat da etnik kimlik vb. gibi konular üzerinden çalışma alanı oluşturmuştur (Erdoğan, 2015, s. 80).

Öyle ki yaşadığı ülkede yabancı, rengiyle dalga geçilen, işyerlerinde ve sokakta ötekileştirilen insanlar çoğunluğu oluşturmalarına rağmen sürekli kendilerini iyi göstermek zorunda hissettirilmiştir. Çok güzel oynamasına ve kendini bulunduğu ülkenin takımına adamasına rağmen siyahî bir futbolcunun gol attığında ya da atamadığında maymun ve goril sesleriyle yuhalanması vb. gibi örnekler günümüzde de bu 1rkçı tutumun yansıması olarak sıkça görülmektedir (İtalya milli takımında forma giyen Balotelli’ye muz atılması vb. gibi).

Hâlbuki her bireyin dünyayı eşit kullanım haklarına sahip olması, var olan her şeyin bütün insanlık için aynı değerde olması ve ateş-hava-su-toprak unsurlarının her yerde bulunması aynı zamanda dünyada yaşayan herkesin eşit olduğu gerçeğini ortaya koymaktadır. Dünya her ulusun, her ulus da dünyanın parçasıdır. Yani "İç içe geçen Matruşka bebekleri gibi, etnik kimlik ulusal kimliğin içinde, ulusal kimlik de ulus-üstü kimliğin içinde olabilir" (Yaldı, 2014, s. 384).

Özellikle ABD'de siyahîlere karşı takınılan ayrımcı tavırdan ötürü çoğunluğu genç olan siyahî Amerikan vatandaşlarının yaşamlarının çeşitli şekillerde yitirilmesi olayı devam etmekte olup, bu haksız tutumlara karşı ayaklanmalar günümüzde de sürmektedir. Missouri eyaletinde silahsız 18 yaşındaki siyahî genç Michael Brown'ın, cumartesi günü kentin çoğunlukla siyahların yaşadığı Ferguson semtinde polis aracında öldürülmesi (Görsel 5) ve 25 Mayıs 2020'de George Floyd'un Minneapolis kentinde beyaz polis Derek Chauvin tarafından öldürülmesi bu örneklerdendir (Görsel 6).

\section{Görsel 5}

Michael Brown'ın Öldürülmesi ile Illgili Bir Yas Görüntüsü

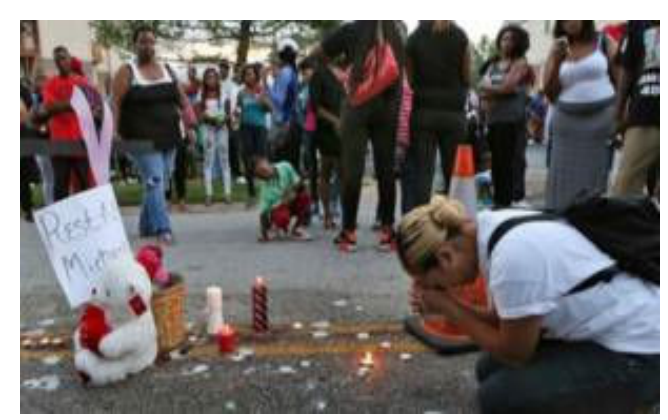

(BBC, 2014)

\section{Görsel 6}

George Floyd'un Öldürülme Anı

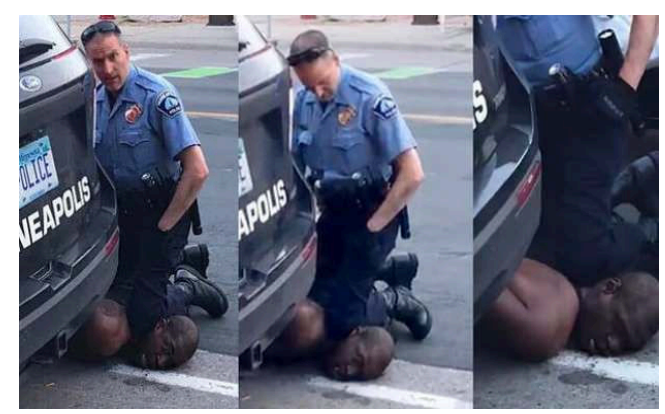

(Haber 7, 2020)

Haksızlıklara ve ötekileştirmeye bir başkaldırı olarak küresel çapta kültürü ve sanatı toplumdaki haksızlıkların giderilmesi ve siyasal dönüşüm için önemli bir yardımcı olarak gören topluluk hareketleri, farklı ve yeni sanat akımlarının oluşum sürecini öne çekmiş oldu. "Bu yüzden hem Feminist Sanat Hareketinin hem de Siyah Sanat Hareketi'nin 1968 Kuşağı olarak bilinen sistem karşıtı genç kuşağın tarafından ortaya konması şaşırtıcı 
sayılmaz" (Ercan, 2019, s. 3). Bu sanatsal akım hareketlerinden birisi de genç İngiliz ressamların oluşturduğu gruptur.

YBA grubu, 1990'lar İngiliz sanatını ve piyasasını şekillendiren, heyecanlandıran bir grup olarak görülür. Bu grupta şimdilerde de sansasyonel işleri, satışlarıyla sanat piyasasını şekillendiren Damien Hirst, Jack\&Dino Chapman, Tracey Emin, Sarah Lucas, Chris Ofili, Sam Taylor-Wood, Tacita Dean, Jenny Saville, Liam Gillick, Angus Fairhurst, Gavin Turk, Fiona Rae, Michael Landy gibi sanatçılar yer alır. YBA grubunun üyelerinin her birinin ayrı ayrı hikâyeleri olduğu söylenebilir. Ancak bu çalışma; sanatçının var olma mücadelesini, piyasa şartlarındaki konumunu koleksiyonerler üzerinden irdeleyebilmek için YBA grubundan olan birkaç sanatçıyı odağa almaktadır. (Selçuk ve Selçuk, 2017, s. 2239).

Bu genç İngiliz ressamlar grubunun siyahî asıllı ressamı Chris Ofili'dir. Ofili; 1968 yılında İngiltere'de doğmuş Nijer kökenli genç İngiliz sanatçısıdır. İngiltere'nin en prestijli ödüllerinden olan Turner ödülünü alan ilk siyahî sanatçıdır. Öteki, ötekileştirme ve kimliksel fikirler üzerinden mağara resimleri, Afrika kültürü ve İncil gibi kaynakları kullanarak çalışmalarını şekillendirmektedir (Özkesici, 2017, s. 1).

\section{Görsel 7}

$X+Y=0$

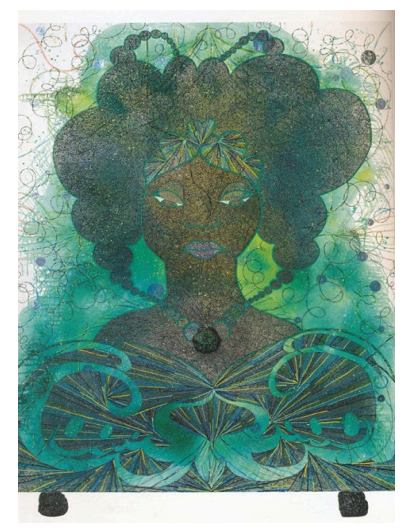

(Ofili, 2000)

Ofili, farklılığı çalışmalarında kullandığı renkler ve malzemelerle elde etmiştir. Özellikle fil dışkısını kendi etnik kimlik ve kültürünün aktarımı olarak kullanır. Fil dışkısı Ofili’nin resimlerinde bir çeşit imza haline gelmiştir ve sanatçının Afrikalı mirasına kültürel bir gönderme niteliğindedir (Doğan, 2014, s. 75). Böylece kendi tavrıyla bir aykırı karşı duruş, başkaldırı, isyan, atalarına yapılanlara karşı yererek vefa ve üstün görülen değerlerin aslında bir başkası için sıradanlığını sergilemektedir.

Sanatçının kültürel gönderme ile yakaladığı orijinalliğin malzemesi olan fil dışkısı; Ofili’’nin çalışmalarını sansasyonel kılmaktadır. Sanatçı fil dışkısını hem tuval üzerinde yerleştirme yaparak hem de tuvali ayakta sergilemek amacıyla destek olarak kullanmaktadır. Hayvanat bahçelerinden edindiği fil dışkısını bir zamanlar siyahîlerin sergilendiği 'insanat bahçelerinin' bulunduğu ünlü mekânlarda bir sanatsal malzeme olarak kullanmaktadır denilebilir.

\section{Görsel 8}

No Woman, No Cry

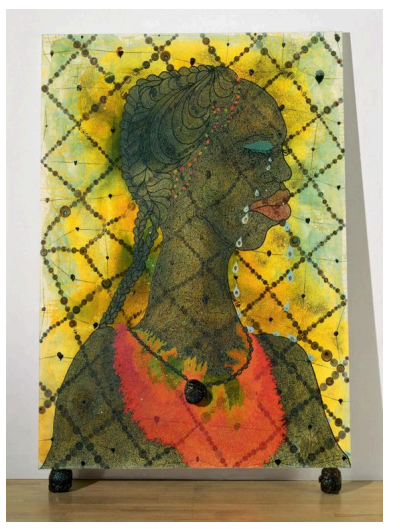

(Ofili, 1998) 
Sanatçı çalışmalarıyla ve eserlerinde kullandığı başkasına göre itici ve iğrenç olan malzemeler ile ırkçılık ve ayrımcılığa karşı bir duruş ortaya koymaktadır. Batının kutsallarını ("Kutsal Bakire Meryem” adlı tablosu örneği) ele alış biçimiyle sorgulatması, Afrikalı karakterini insanların nasıl algıladığını ve bu çizgide toplumsal sorunları kendine has tarzıyla yansıtmaktadır. Ofili'nin çalışmalarında kullandığ kültürel hem de postkolonyal mesajlar vermektedir (Demir, 2019, s. 470-479).

\section{Görsel 9}

Chris Ofili'nin “Kutsal Bakire Meryem” Adlı Eserine Yönelik Protestolardan Bir Kare

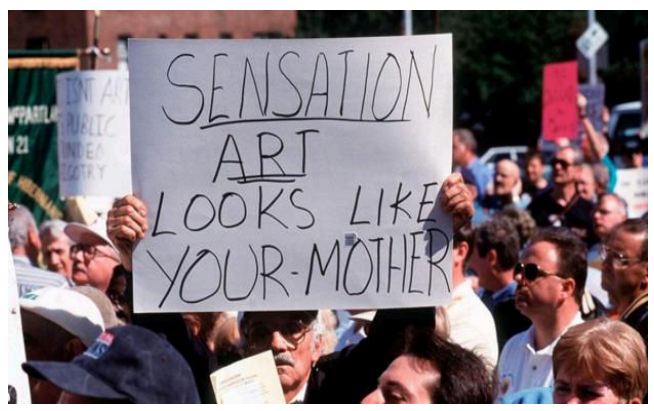

(Leynse Corbis, 1999)

Ofili, yaptığı çalışmalarla insanlarda özellikle de Batı toplumlarında şok etkisi oluşturarak eleştiri ve protestolara maruz kalmıştır. (Sooke, 2014) Çünkü artık siyahî asıllı bir ressam Batının tam merkezi sayılan mekânlarda kendi etnik kimliğiyle "beyazların" birtakım kutsallarını alaycı bir biçimde ele alarak adeta yapılan ırkçı ve ayrımcı tutumlara bir tepki üretmektedir.

\section{Sonuç}

İnsan hata yapan ve yaptığı hatayı unutarak tekrarlayan bir varlıktır. Yüzyılların tarihi bilgileri ve belgeleri bunu defalarca bizlere göstermiştir. İktidar sahiplerinin kendi etnik kimlikleri üzerinden üstü kapalı (!) ayrımcılık ve üstünlük politikaları, tarih boyunca çoğu kez toplu yerinden edilişler, kültürel ve etnik çatışmalara yol açmıştır. Değişen dünyada güya modernleşmenin ve refahın zirvesi olan günümüzde bile bu sorunların (ırkçılık, ötekileştirme vb.) halen daha sürmanşetlerin satır başlarını süslüyor olması bu durumun göstergesi olarak karşımızda durmaktadır.

Tarihin farklılaşması ile değişen görüşlere göre kimi zaman taklit kimi zamanda arınma olarak görülen sanat; çağların, toplumun ve kültürün değişmez ve vazgeçilmez bir parçası olarak toplumda meydana gelen sorunlar, olaylar ve değişimleri kendi argümanları üzerinden yansıtmaya devam etmektedir. Güncel sanat ise bu süreci manipüle ederek (Ofili’nin The Holy Virgin Mary çalışması vb. gibi), performansa dayalı (Abramoviç, Joge, Beuys vb. gibi) ya da Video Art'larıyla güncel konuları ele almaktadır. Bu güncel konular arasında araştırma neticesinde ötekileştirme kavramının oldukça önemli bir yer tuttuğu görülmüştür. Ötekileştirme karikatürlerde, sinemalarda ya da gerçek yaşamda olduğu gibi resim ve heykel sanatında da geniş bir etki oluşturmuştur. Araştırma sonucunda devletlerin, kralların ya da burjuvazinin ötekileştirmeyi sanatın ince mesajlarıyla vurguladıkları ortaya konulmuştur. Fakat günümüzde artık her ülke ve bölgeden sanatçılar yapıtlarıyla ilgileri üzerine çekebilmektedir. Göçlerin meydana getirdiği kozmopolitlik sanatçıların kendi öz kimliklerini sorgulamasına sebep olmuştur. Böylelikle güncel sanat belleği hem öteki olanı alaycı ele alabilmekte hem de kendi kültürel geçmişini canlandıran göndermeler barındırabilmektedir. Bu farklılık kimi grupları bu sanatçıların yaptıkları alaycı çalışmaları protesto etmeye yönlendirmektedir.

Chris Ofili'de çalışmalarıyla ve ortaya koyduklarıyla bu kapital, ayrıştırıcı, sömürü zamanının karşısında duran ve çalışmalar üreten sanatçılardandır. Çalışmalarında siyahî kimliği, Afrika köklerini, batı medeniyetinin atalarına ve diğer toplumlara bakış açılarını ve tutumlarını yine batının birtakım kutsallarını alaycı bir biçimde ele alarak ince mesajlarla ortaya koymuştur. Chris Ofili, yaptığı çalışmalarla yeni nesillere kendi kültürünü korumak, kimliğine sahip çıkmak ve sorgulamadan kabullenmemek gibi mesajlar bırakmıştır denilebilir. Bu çalışmada da bu etnik yaklaşımların sanatsal yansımaları ve Chris Ofili’nin özgün duruşu öznel yorumlamalarla ele alınmıştır.

\section{Kaynakça}

Ağçiçek, M. (1991). Çăgdaş resimde tasarım süreci (Tez No. 17521) [Yüksek Lisans Tezi, Mimar Sinan Güzel Sanatlar Üniversitesi, Sosyal Bilimler Enstitüsü]. Yükseköğretim Kurulu Tez Merkezi.

Akkaya, C. (2007). Yeni-dışavurumcu resimde şiddetin ve gerilimin ifade aracı olarak renk (Tez No. 219434) [Yüksek Lisans Tezi, Dokuz Eylül Üniversitesi, Güzel Sanatlar Enstitüsü]. Yükseköğretim Kurulu Tez Merkezi. 
Andırın, M. (2019). 1960 sonrası çağdaş sanatta suyun kullanımı (Tez No. 584899) [Yüksek Lisans Tezi, Işık Üniversitesi, Sosyal Bilimler Enstitüsü]. Yükseköğretim Kurulu Tez Merkezi.

Ataseven, Y. S. (2011). Çă̆daş figüratif resimde geleneğe dönüş ve “yeni-eski ustalar” (Tez No. 289470) [Sanatta Yeterlik, Dokuz Eylül Üniversitesi, Güzel Sanatlar Enstitüsü]. Yükseköğretim Kurulu Tez Merkezi.

Atlı, Ş. (2018). Çăgdaş sanatta yerel/ geleneksel imgelerin radikal kullanımı (Tez No. 530779) [Yüksek Lisans Tezi, Mardin Artuklu Üniversitesi, Sosyal Bilimler Enstitüsü]. Yükseköğretim Kurulu Tez Merkezi.

Avrupa Birliği Gazetesi. (2016). Insan hayvanat bahçesi [Fotoğraf]. Avrupa Birliği Gazetesi. http://avrupabirligigazetesi.com.tr/2016/11/25/insan-hayvanat-bahcesi/

Barker, T. J. (1863). Kraliçe Viktorya Windsor şatosunun kabul salonunda İncil sunarken. [Yağlı Boya Tablo]. Twitter Web Client. https://twitter.com/acephaleart/status/1042346389697638400?lang=cs

BBC. (2014). Michael Brown’ın öldürülmesi ile ilgili bir yas görüntüsü [Fotoğraf]. BBC News. https://www.bbc.com/turkce/haberler/2014/08/140811_abd_siyah_isyan

Bilen, İ. S. (2019). Alev Alatlı’ya göre Doğu ve Batı toplumlarında insanın konumlandırılışı. Uluslararası Beşeri ve Sosyal Bilimler Inceleme Dergisi, 3(1), 17-25. https://dergipark.org.tr/tr/download/articlefile/708224

Creswell, W. C. (2020). Beş nitel araştırma yaklaşımı. M. Bütün \& S. B. Demir (Ed.), Nitel araştırma yöntemleri (s. 71-112) içinde. Siyasal Kitabevi. (Orijinal çalışma 2013’te yayınlanmıştır).

Çolak, İ. (2018). Batı'nın ırkçı kodları. Zafer Bilim Araştırma Kültür Sanat Dergisi, 502. Erişim adresi: https://www.zaferdergisi.com/makale/10677-batinin-irkci-kodlari.html

Demir, G. (2019). İronik ve egzotik ofili etkisi (sanatta bir karşı saldırı). SDÜ ART-E Güzel Sanatlar Fakültesi Sanat Dergisi, 12(24), 462-482. https://doi.org/10.21602/sduarte.612504

Doğan, H. (2014). Çăgdaşs sanatta çirkinlik (Tez No. 366971) [Yüksek Lisans Tezi, Atatürk Üniversitesi, Sosyal Bilimler Enstitüsü]. Yükseköğretim Kurulu Tez Merkezi.

Ercan, D. B. (2019). Feminist sanat hareketi ve Filistinli kadın sanatçılar (Tez No. 568894) [Yüksek Lisans Tezi, Batman Üniversitesi, Sosyal Bilimler Enstitüsü]. Yükseköğretim Kurulu Tez Merkezi.

Erdoğan, M. (2015). Küresel çağda çağdaş sanat ve küresel sanat pazarı. Anadolu Üniversitesi Sosyal Bilimler Dergisi,15(1), 75-98. https://doi.org/10.18037/ausbd.98486

Erkayhan, Ş., \& Ödekan, A. (2008). Almanya'da yeni nesil Türk sanatçılar ve hayali vatan: Türkiye. Ittü Dergisi/b Sosyal Bilimler, $20-30$. http://itudergi.itu.edu.tr/index.php/itudergisi_b/article/viewFile/102/88

Gazi, A. M., \& Çakı, C. (2018). Siyahî ayrımcılığa karşı hazırlanan kamu spotu reklamları. International Journal of Labour Life and Social Policy, 1(2), 48-62. https://dergipark.org.tr/tr/download/articlefile/602758

Haber 7. (2020). George Floyd'un öldürülme anı [Fotoğraf]. Haber 7. https://www.haber7.com/dunya/haber/ 2983256-iste-cinayetin-bedeli-kefalet-ucreti-belli-oldu

Hovenden, T. (1885). Olmamış mı? (Ain't That Ripe?) [Yağlı Boya Tablo]. T24. https://t24.com.tr/yazarlar/ cebrail-otgun/gulmenin-sessiz-imgeleri,26219

Leppert, R. (1996). Sanatta anlamın görüntüsü. (İ. Türkmen, Çev.). Ayrıntı Yayınları. (Orijinal çalışma 1996’da yayınlanmıştır).

Leynse Corbis, J. (2014). A new exhibition by British artist Chris Ofili has been greeted with rapturous praisewhere once his Works was surrounded by controversy. What's changed? Alastair Sooke explains [Fotoğraf]. BBC. http://www.bbc.com/culture/story/20141125-can-art-still-shock-us

Library of Congress. (1906). Ota Benga at Bronx [Fotoğraf]. Wikimedia Commons. https://tr.wikipedia.org/wiki/Ota_Benga\#/media/Dosya:Ota_Benga at_Bronx_Zoo.jpg

Ofili, C. (1998). No woman, no cry [Yağlı Boya Tablo]. Culturetrip. https://theculturetrip.com/europe/unitedkingdom/england/london/articles/the-10-unmissable-works-to-see-at-tate-britain/

Ofili, C. (2000). $X+Y=0$ [Yağlı Boya Tablo]. Pinterest. https://www.pinterest.it/pin/15129348732759999/ 
Özer, S. (2007). 19. Yüzyılda Mısır'da kölelik ve köle ticareti. Fırat Üniversitesi Orta Doğu Araştırmaları Dergisi, 5(1), 65-84. https://dergipark.org.tr/tr/download/article-file/1670483

Özkesici, E. (2017). “Öteki” kavramı üzerine görsel çözümlemeler (Tez No. 469202) [Sanatta Yeterlik, Hacettepe Üniversitesi, Güzel Sanatlar Enstitüsü]. Yükseköğretim Kurulu Tez Merkezi.

Selçuk, Ü., \& Selçuk, E. (2017). Sanat piyasası ve sanatçı. İdil Dergisi, 6(36), 2233-2244. https://doi.org/10.7816/idil-06-36-06

Sooke, A. (2014, Kasim 25). A new exhibition by British artist Chris Ofili has been greeted with rapturous praise whereonce his work was surrounded by controversy. What's changed? Alastair Sooke explains. $B B C$. http://www.bbc.com/culture/story/20141125-can-art-still-shock-us

Tarzan, Ö. (2010). Yeni dışavurumcu tavrı oluşturan sanatçı kimliği ve yapıtlardaki psiko-sembolik öğeler (Tez No. 293235) [Yüksek Lisans Tezi, Dokuz Eylül Üniversitesi, Güzel Sanatlar Enstitüsü]. Yükseköğretim Kurulu Tez Merkezi.

Yaldız, F. (2014). Uluslararası göç ve diaspora ile ilişkili kavramlar. Insan ve Toplum Bilimleri Araştırmaları Dergisi, 3(2), 382-403. https://doi.org/10.15869/itobiad.24114

Yıldırım, A., \& Şimşek, H. (2009). Sosyal bilimlerde nitel araştırma yöntemleri (18. baskı). Seçkin Yayıncılık. 